\title{
There is no such thing as a tree of life (and of course viruses are out!)
}

\section{Didier Raoult}

Moreira and López-García put forward their review (Ten reasons to exclude viruses from the tree of life. Nature Rev. Microbiol. 7, $306-311(2009))^{1}$ as a decalogue on the position of giant viruses in the tree of life, mainly directed against our work on Mimivirus ${ }^{2}$. My opinion is that, according to K. Popper ${ }^{3}$, this reaction is more religious than scientific, and more the result of deductions than observed data. I propose an eleventh reason to exclude viruses from the tree of life: there is no such thing as a tree of life. The idea of a tree of life, which stringently follows Darwin theor ${ }^{4}$, is not pertinent in the genomic age ${ }^{5}$. Because of the occurrence of lateral gene transfer, specifically in the 'mobilome' category of selfish genes, we know that current organisms are chimeric, and made of a mosaic of sequences of different origins that makes the tree of life theory obsolete ${ }^{6}$. This indeed accords with the view of R. Dawkins (the selfish gene) ${ }^{7}$, and makes the tree look more like a forest ${ }^{5}$. The tree propounded by Darwin would be obtained only gene by gene, and possibly is pertinent mainly for 16 S ribosomal DNA; of course this excludes viruses that are devoid of ribosomes. However, Mimivirus has many genes of different origins, allowing us to create many trees of different forms.

There is no universal tree, and life has no scientific sense either. Life should not be defined by considering only definitive biological properties; our definition of life should evolve to integrate all of our knowledge at a specific moment. Therefore, to define life (if one would want to, and there is no consensus on this), all known biological data should be integrated. It is difficult to differentiate the 'life' of giant viruses such as Mimivirus from many proteins, RNA and genes, and to differentiate the same genetic code from that of intracellular Archaea and
Bacteria. Moreover, large viruses have a similar size and life cycle, within a created vacuole (the viral factory), as intracellular bacteria such as Chlamydia ${ }^{2}$. Finally, giant viruses also have their own viral parasites ${ }^{8}$. Indeed, viruses are a part of biology (a word that is derived from the Greek 'biola', meaning the study of life). The controversy about the word 'life' (also quoted as unscientific by K. Popper ${ }^{3}$ ) is not my 'cup of tea'. If I had to choose a definition of life, I would prefer that of Shakespeare in Macbeth: it is "A tale, told by an idiot, full of sound and fury, signifying nothing." Finally, I am primarily a biologist (a man studying life, etymologically), and I am therefore happy to provide data challenging old concepts and definitions. If this is hurting dogmas I do not really care, and I repeat, as quoted by Galileo in response to church sanctions, "eppur si muove", meaning that facts will resist theories.

Didier Raoult is at the Unité de recherche en maladies infectieuses et tropicales émergentes, CNRS-IRD UMR 6236, Faculté de médecine, Université de la méditerranée, 27 boulevard Jean Moulin, 13385 Marseille, France. e-mail: Didier.Raoult@gmail.com

1. Moreira, D. \& López-García, P. Ten reasons to exclude viruses from the tree of life. Nature Rev. Microbiol. 7 306-311 (2009).

2. Raoult, D. \& Forterre, P. Redefining viruses: lessons from Mimivirus. Nature Rev. Microbiol. 6, 315-319 (2008).

3. Popper, K. The Logic of Scientific Discovery (Taylor \& Francis Group, London, 2002).

4. Raoult, D. Creationism - remember the principle of falsifiability. Lancet 372, 2095-2096 (2008).

5. Koonin, E. V. Darwinian evolution in the light of genomics. Nucleic Acids Res. 37, 1011-1034 (2009).

6. Doolittle, W. F. \& Bapteste, E. Pattern pluralism and the Tree of Life hypothesis. Proc. Natl Acad. Sci. USA 104, 2043-2049 (2007).

7. Dawkins, R. The Selfish Gene (Oxford Univ. Press, 2006).

8. La Scola, B. et al. The virophage as a unique parasite of the giant mimivirus. Nature 455, 100-104 (2008). 